\title{
Complete genome sequence of Treponema pallidum strain DAL-1
}

\author{
Marie Zobaníková ${ }^{,}$, Pavol Mikolka ${ }^{1}$, Darina Čejkováa ${ }^{1,2,3}$, Petra Pospíšilová1,2, Lei Chen ${ }^{2,3}$, \\ Michal Strouhal ${ }^{1,3}$, Xiang Qin ${ }^{2}$, George M. Weinstock ${ }^{2,3}$, and David Šmajs ${ }^{1 *}$ \\ ${ }^{1}$ Department of Biology, Faculty of Medicine, Masaryk University, Brno, Czech Republic \\ ${ }^{2}$ Human Genome Sequencing Center, Baylor College of Medicine, Houston, Texas, USA \\ ${ }^{3}$ The Genome Institute, Department of Genetics, Washington University School of Medi- \\ cine, St. Louis, Missouri, USA
}

*Corresponding author: David Šmajs; dsmajs@med.muni.cz

Keywords: Spirochaetaceae, Treponema pallidum, syphilis

\begin{abstract}
Treponema pallidum strain DAL-1 is a human uncultivable pathogen causing the sexually transmitted disease syphilis. Strain DAL-1 was isolated from the amniotic fluid of a pregnant woman in the secondary stage of syphilis. Here we describe the 1,139,971 bp long genome of $T$. pallidum strain DAL-1 which was sequenced using two independent sequencing methods (454 pyrosequencing and Illumina). In rabbits, strain DAL-1 replicated better than the $T$. pallidum strain Nichols. The comparison of the complete DAL-1 genome sequence with the Nichols sequence revealed a list of genetic differences that are potentially responsible for the increased rabbit virulence of the DAL-1 strain.
\end{abstract}

\section{Introduction}

Treponema pallidum is an uncultivable human pathogen causing the sexually transmitted disease, syphilis. Until now, three syphilis causing strains of $T$. pallidum have been completely sequenced including strain Nichols [1], SS14 [2], and Chicago [3]. In addition, a number of related treponemes causing yaws including strains Samoa D, CDC-2, Gauthier [4] and $T$. paraluiscuniculi strain Cuniculi A [5] have been sequenced. The data indicates that pathogenic treponemes are extremely closely related and small genetic changes can result in profound changes in pathogenesis and host range [6]. The accumulation of genomic data provides new insights into the pathogenesis of treponemal diseases and into the evolution of pathogenic treponemes and brings new opportunities for molecular diagnostics of syphilis [6]. T. pallidum strain DAL-1 was isolated using intratesticular injection of rabbits with amniotic fluid taken from a 21-year-old African American woman (at 35 weeks of gestation) in the secondary stage of syphilis [7]. In rabbits, the DAL-1 strain replicated better than the Nichols strain [1,7]. Therefore, the genome sequencing of the DAL-1 strain and its comparison with the Nichols sequence should reveal a list of genetic differences that are potentially responsible for increased rabbit virulence of the DAL-1 strain.

\section{Classification and features}

Treponema pallidum, previously known as Spirochaeta pallida [8], is an etiologic agent of syphilis. Based on DNA hybridization studies [9], Treponema pallidum and yaws [10] causing Treponema pertenue were found to be genetically indistinguishable. The rabbit pathogen, Treponema paraluiscuniculi, is not pathogenic to humans and the sequence identity is greater than $98 \%$ on a genome wide scale [5]. The genus Treponema belongs to the family Spirochaetaceae (see Table 1). Genetic relatedness of T. pallidum strain DAL-1 to other treponemes and spirochetes is shown in Figure 1.

T. pallidum is a Gram-negative, spiral shaped bacterium 6 to $15 \mu \mathrm{m}$ in length and $0.2 \mu \mathrm{m}$ in diameter. T. pallidum is an anaerobic non sporeforming motile bacterium that moves by rotating 
Zobanikova et al.

around its longitudinal axis. This movement is powered by endoflagella located in the periplasmic space. The cell wall is composed of a cytoplasmic membrane, a thin peptidoglycan layer, a periplasmic space with endoflagella, and an outer membrane [31].

T. pallidum is an obligate human parasite, which does not survive outside its mammalian host and cannot be cultivated continuously under in vitro conditions. Optimal conditions for time-limited cultivation in tissue culture consisted of temperature between $33{ }^{\circ} \mathrm{C}$ and $35{ }^{\circ} \mathrm{C}$, atmospheric oxygen concentration in the 1.5 to $5 \%$ range, $20 \%$ fetal bovine serum in the culture medium and the testes extract [21]. Cultivation in tissue cultures resulted in approximately 100 -fold multiplication $[32,33]$. Stable propagation of T. pallidum strains can only be achieved in mammalian hosts, usually rabbits.

T. pallidum is sensitive to high temperatures $[21,34]$, and is catalase- and oxidase-negative. As a consequence of its small genome, T. pallidum has limited metabolic capacity in general [1-3]. Most essential macromolecules are taken up from the host by a number of transport proteins with broad substrate specificity. In total, 113 genes of T. pallidum encode proteins involved in transport, which compensate for the absence of genes encoding components of the tricarboxylic acid cycle, oxidative phosphorylation, components for de novo synthesis of amino acids, fatty acids, enzyme cofactors and nucleotides [1].

Susceptibility of $T$. pallidum to antimicrobial agents has been tested in tissue culture models followed by testing of treponemal viability using intradermal inoculation of rabbits [35]. No skin lesions were detected following injections of penicillin G: $0.0025 \mu \mathrm{g} / \mathrm{ml}$; tetracycline: $0.5 \mu \mathrm{g} / \mathrm{ml}$; erythromycin: $0.005 \mu \mathrm{g} / \mathrm{ml}$; and spectinomycin: $0.5 \mu \mathrm{g} / \mathrm{ml}$, indicating that no viable bacteria were present following antibiotic treatment. Unlike penicillin, macrolide regimens have a risk of treatment failure due to chromosomally encoded resistance in T. pallidum [36,37].

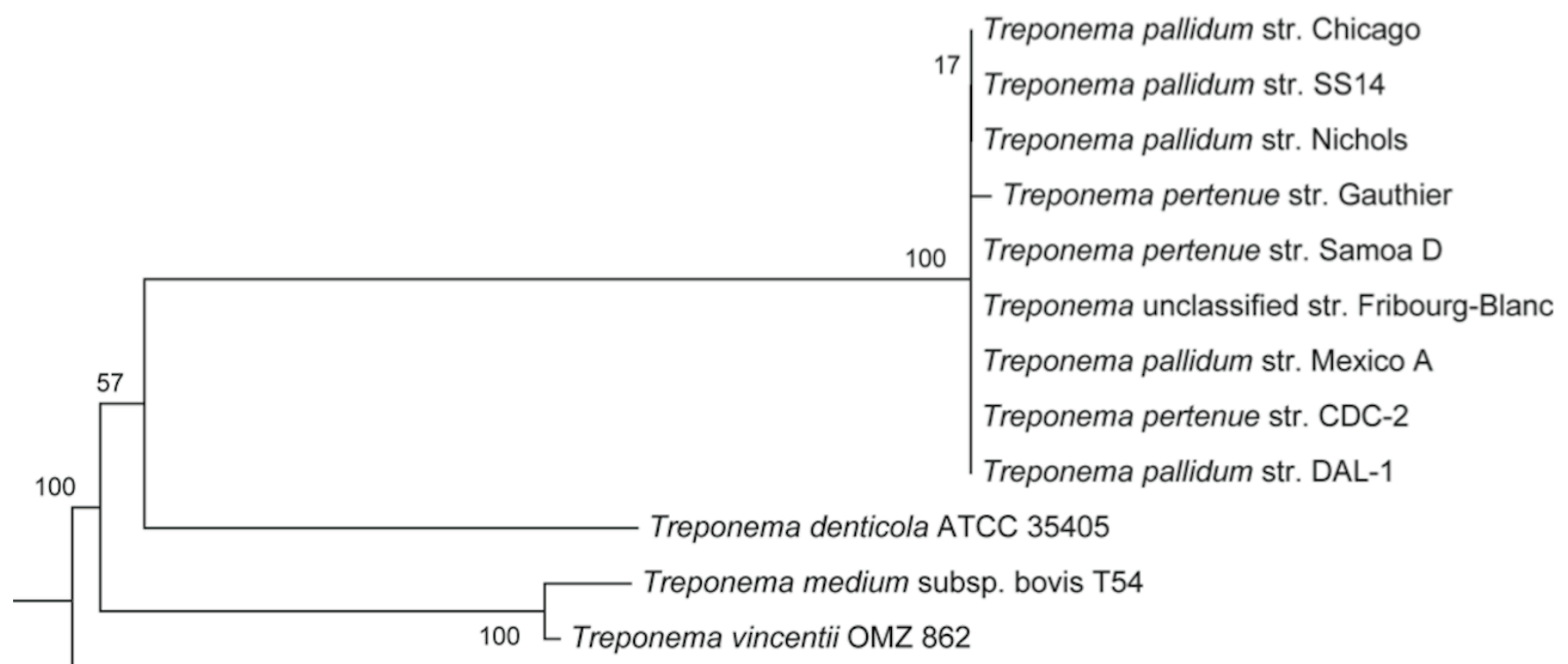

Spirochaeta zuelzerae type strain DSM 1903_2

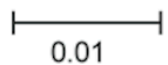

Figure 1. Phylogenetic tree based on $16 \mathrm{~S}$ rRNA of T. pallidum DAL-1 and some strains of Treponema species. The bar scale represents the number of nucleotide substitutions per $1 \mathrm{nt}$ site. The tree was generated using tree-builder, which is available from the Ribosomal Database project [28], using the Weighbor (weighted neighbor-joining) algorithm [29] and the Jukes-Cantor distance correction [30]. A Spirochaeta zuelzerae type strain was used as the outgroup. 


\begin{tabular}{|c|c|c|c|}
\hline MIGS ID & Property & Term & Evidence code $^{\mathrm{a}}$ \\
\hline & Current classification & Domain Bacteria & TAS [12] \\
\hline & & Phylum Spirochaetes & TAS [13] \\
\hline & & Class Spirochaetes & TAS [14,15] \\
\hline & & Order Spirochaetales & TAS $[16,17]$ \\
\hline & & Family Spirochaetaceae & TAS $[17,18]$ \\
\hline & & Genus Treponema & TAS $[17,19,20]$ \\
\hline & & Species Treponema pallidum & TAS $[17,20]$ \\
\hline & & strain DAL-1 & TAS [7] \\
\hline & Gram stain & negative & TAS [8] \\
\hline & Cell shape & spiral-shaped & TAS [7] \\
\hline & Motility & motile & TAS [7] \\
\hline & Sporulation & none & TAS [8] \\
\hline & Temperature range & mesophilic & TAS [21] \\
\hline & Optimum temperature & $33-35^{\circ} \mathrm{C}$ & TAS [21] \\
\hline \multirow[t]{3}{*}{ MIGS-22 } & Oxygen & anaerobic & TAS [22] \\
\hline & Carbon source & carbohydrates & TAS [23] \\
\hline & Energy metabolism & chemoorganotroph & TAS $[23,24]$ \\
\hline MIGS-6 & Habitat & host associated & TAS [8] \\
\hline MIGS-6.3 & Salinity & not reported & \\
\hline MIGS-15 & Biotic relationship & parasitic & TAS [8] \\
\hline \multirow[t]{7}{*}{ MIGS-14 } & Pathogenicity & pathogenic & TAS [8] \\
\hline & Host & Homo sapiens & TAS [25] \\
\hline & Host taxa Id & 9606 & \\
\hline & Disease & syphilis & TAS [8] \\
\hline & Cell arrangement & single & TAS [8] \\
\hline & Biosafety level & 2 & TAS [26] \\
\hline & Isolation & amniocentesis & TAS [7] \\
\hline MIGS-4 & Geographic location & Dallas, TX, USA & TAS [7] \\
\hline MIGS-5 & Sample collection time & 1991 & TAS [7] \\
\hline MIGS-4.1 & Latitude & & \\
\hline MIGS-4.2 & Longitude & not reported & \\
\hline MIGS-4.3 & Depth & not reported & \\
\hline MIGS-4.4 & Altitude & not reported & \\
\hline
\end{tabular}

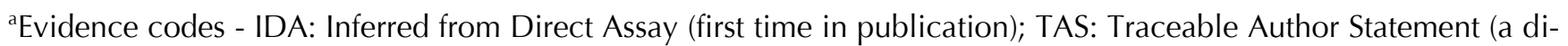
rect report exists in the literature); NAS: Non-traceable Author Statement (not directly observed for the living, isolated sample, but based on a generally accepted property of the species, or anecdotal evidence). These evidence codes are from the Gene Ontology project [27].

\section{Genome sequencing information Genome project history}

This organism was selected for sequencing on the basis of its increased virulence in rabbits compared to the Nichols strain [1]. The genome project is deposited in the Genomes On Line Database
[38] and the complete genome sequence is available at the GenBank (CP003115). The details of the project are summarized in Table 2 . 
Table 2. Project information

\begin{tabular}{lll}
\hline MIGS ID & Property & Term \\
\hline MIGS-31 & Finishing quality & finished \\
MIGS-28 & Libraries used & one 454 fragment library, one Illumina \\
MIGS-29 & Sequencing platforms & 454 GS20, Illumina GA \\
MIGS-31.2 & Sequencing coverage & $45 \times 454,91 \times$ Illumina \\
MIGS-30 & Assemblers & Newbler 1.0.53.17, Velvet 0.6.05, SeqMan \\
MIGS-32 & Gene calling method & FgenesB, Glimmer, GeneMark, tRNA-Scan, RNAmmer, Rfam \\
& Genbank ID & CP003115 \\
& Genbank Date of Release & February 8, 2012 \\
& GOLD ID & Gi01869 \\
& Genome Db & BCM-HGSC \\
& Project relevance & uncultivable human pathogen, medical \\
\hline
\end{tabular}

\section{Growth conditions and DNA isolation}

Strain DAL-1 was grown in rabbit testis, treponemes were extracted and purified from testicular tissue using Hypaque gradient centrifugation $[1,39]$. Chromosomal DNA was prepared as described previously [1].

\section{Genome sequencing and assembly}

The genome of strain DAL-1 was sequenced using a combination of Illumina and 454 sequencing platforms (GS20). Pyrosequencing reads (506,607 raw reads of total read length $51,283,327$ bp) showing sequence similarity to the Nichols genome sequence [1] were assembled using the Newbler assembler version 1.0.53.17 into 235 contigs (45× genome coverage). Newbler contigs were assembled according to the reference Nichols genome [6] using Lasergene software (DNASTAR, Madison, WI, USA), this assembly reduced the number of contigs to 52 separated by 52 gaps (total length of 19,545 bp). Gaps between contigs were closed using Sanger sequencing. Altogether, 43 individual PCR products were sequenced including 5 XL-PCR products. The PCR products were sequenced using amplification and, when required, internal primers. In addition, 4 libraries of XL-PCR products were prepared and sequenced. The resulting complete genome sequence of strain DAL-1 was considered to be a draft sequence. Additional Illumina sequencing was applied to improve genome sequencing accuracy and the complete DAL- 1 genome sequence was compiled from these data. A total of 2,881,557 raw Illumina reads (total length of 103,736,052 bp) were assembled, using the Velvet 0.6.05 assembler [40], into 303 contigs (with $91 \times$ average coverage). Out of these 303 contigs, 295 showed sequence similarities to the T. pallidum Nichols genome leaving $46,148 \mathrm{bp}$ of $T$. pallidum DAL-1 unsequenced using the Illumina method. Each DAL-1 region not sequenced by Illumina and containing differences from the Nichols genome was resequenced using the Sanger method. In addition, all other discrepancies between the complete DAL-1 genome sequence and the Nichols genome sequence were resolved using Sanger sequencing of both DAL-1 and Nichols strains. Altogether, 15 errors were identified in the 1,093 $\mathrm{kb}$ Illumina resequenced region, indicating that the complete DAL-1 genome sequence contained 1 error per 73 kbp. Therefore, the final, corrected, strain DAL-1 genome sequence has an error rate less than $10^{-5}$.

\section{Genome annotation}

Strain DAL-1 genome was annotated with gene coordinates taken from the Nichols [1], SS14 [2] and Samoa D [4] genomes. These coordinates were adapted and recalculated. Genes identified in the DAL-1 genome were denoted with the prefix TPADAL followed by four numbers to indicate the gene number. Newly predicted genes were identified using the GeneMark and Glimmer programs. In most cases, the original locus tag values of annotated genes were preserved in the DAL-1 orthologs. Newly predicted genes in the DAL-1 genome were named according to the preceding gene with a letter suffix (e.g. TPADAL_0950a). 


\section{Genome properties}

The genome consists of a single circular DNA chromosome, $1,139,971 \mathrm{bp}$ in length. The $\mathrm{G}+\mathrm{C}$ content is $52.8 \%$ (Figure 2, Table 3). Out of the 1,122 predicted genes, 1,068 genes were protein-coding. A set of 54 genes coded for RNA and 9 were identi- fied as pseudogenes. The majority of the proteincoding genes (61.6\% of all genes) were assigned a putative function while $33.6 \%$ of all genes code for proteins with unknown function. The distribution of genes into COGs functional categories is presented in Figure 2 and Table 4.

Table 3. Genome Statistics

\begin{tabular}{lrr}
\hline Attribute & Value & \% of Total $^{\mathbf{a}}$ \\
\hline Genome size (bp) & $1,139,971$ & 100.00 \\
DNA coding region (bp) & $1,073,595$ & 94.2 \\
DNA G+C content (bp) & 601,817 & 52.8 \\
Number of replicons & 1 & \\
Extra-chromosomal elements & 0 & \\
Total genes & 1,122 & 100.00 \\
RNA genes & 54 & 4.8 \\
rRNA operons & 2 & \\
Protein-coding genes & 1,068 & 95.2 \\
Pseudogenes & 9 & 0.8 \\
Protein coding genes with function prediction & 691 & 61.6 \\
Protein coding genes in paralog clusters & 178 & 15.9 \\
Protein coding genes assigned to COGs & 756 & 67.4 \\
Protein coding genes assigned Pfam domains & 763 & 68.0 \\
Protein coding genes with signal peptides & 203 & 18.1 \\
Protein coding genes with transmembrane helices & 260 & 23.2 \\
\hline
\end{tabular}

abased either on the size of the genome in base pairs or the total number of protein coding genes in the annotated genome

\section{Insights into the genome}

Sequence changes differentiating the DAL- 1 and Nichols genomes were identified mainly in the TPADAL_0136 gene (encoding fibronectin binding protein [42]) and comprised 94 nt changes. In addition, a repeat containing gene, TPADAL_0470 was found to contain 288 nts insertion composed of twelve, 24-bp repetitions. tpr genes including $t p r \mathrm{~F}$ (TP0316), tprG (TP0317) and tprK (TP0897) contained 2, 1 and 4 nt changes, respectively. However, the tprK gene was found variable within the DAL- 1 strain and therefore the reported $4 \mathrm{nt}$ changes do not refer to the variable tprK region [43]. Tpr proteins are known virulence factors in treponemes [43-48] and the changes in the primary sequence of the protein may be of importance in increased DAL-1 rabbit virulence. In addition to the changes in the above mentioned genes, additional 31 nt changes were found throughout the genome $(6$ single nucleotide deletions, 3 single nucleotide insertions, 16 single nucleotide substitutions, one 2-nt deletion and one 4-nt deletion). All the indels (with exception of the 4-nt deletion) were found to be located in the $G$ or $C$ homopolymers. Indels resulted in truncation or elongation of several proteins including TPADAL_0012 (hypothetical protein, finally not annotated), TPADAL_0040 (probable methylaccepting chemotaxis protein), TPADAL_0067 (conserved hypothetical protein), TPADAL_0127a (hypothetical protein), TPADAL_0134a (hypothetical protein), TPADAL_470 (conserved hypothetical protein), TPADAL_0479 (hypothetical protein), and TPADAL_0609 (AsnS, asparagine-tRNA ligase). In addition, TPADAL_0859-860 was identified as a fused protein (TPADAL_0859). Two of the indels in the $\mathrm{G}$ or $\mathrm{C}$ homopolymers were found in the intergenic regions (IGR TPADAL_0225-226, IGR TPADAL_0316-317). Since G homopolymers, of variable length, affected gene expression rates of tpr genes [49], these differences may change the gene expression pattern in the DAL-1 genome. Out of the 16 single nucleotide substitutions, 3 were located in intergenic regions (IGR TPADAL_0126c0126d, IGR TPADAL_0582-584, IGR 
TPADAL_0698-700) and three resulted in synonymous mutations (TPADAL_0228, 0742, 0939). The remaining 10 substitutions resulted in 9 nonsynonymous changes in TPADAL_0051 (prfA, peptide chain release factor RF1), TPADAL_0065 (probable SAM dependent up methyltransferase), TPADAL_0279 (bifunctional cytidylate kinase/ribosomal protein S1), TPADAL_0433 (arp, a repeat containing gene), TPADAL_0674 (encoding conserved hypothetical protein), TPADAL_0720 (fliY, bifunctional chemotaxis protein CheC/flagellar motor switch protein FliY), and TPADAL_0854 (encoding conserved hypothetical protein). All of the above listed genes and all the changes in the intergenic regions (potentially affecting gene expression rates) should be considered as potential reason for the observed increased virulence in rabbits.

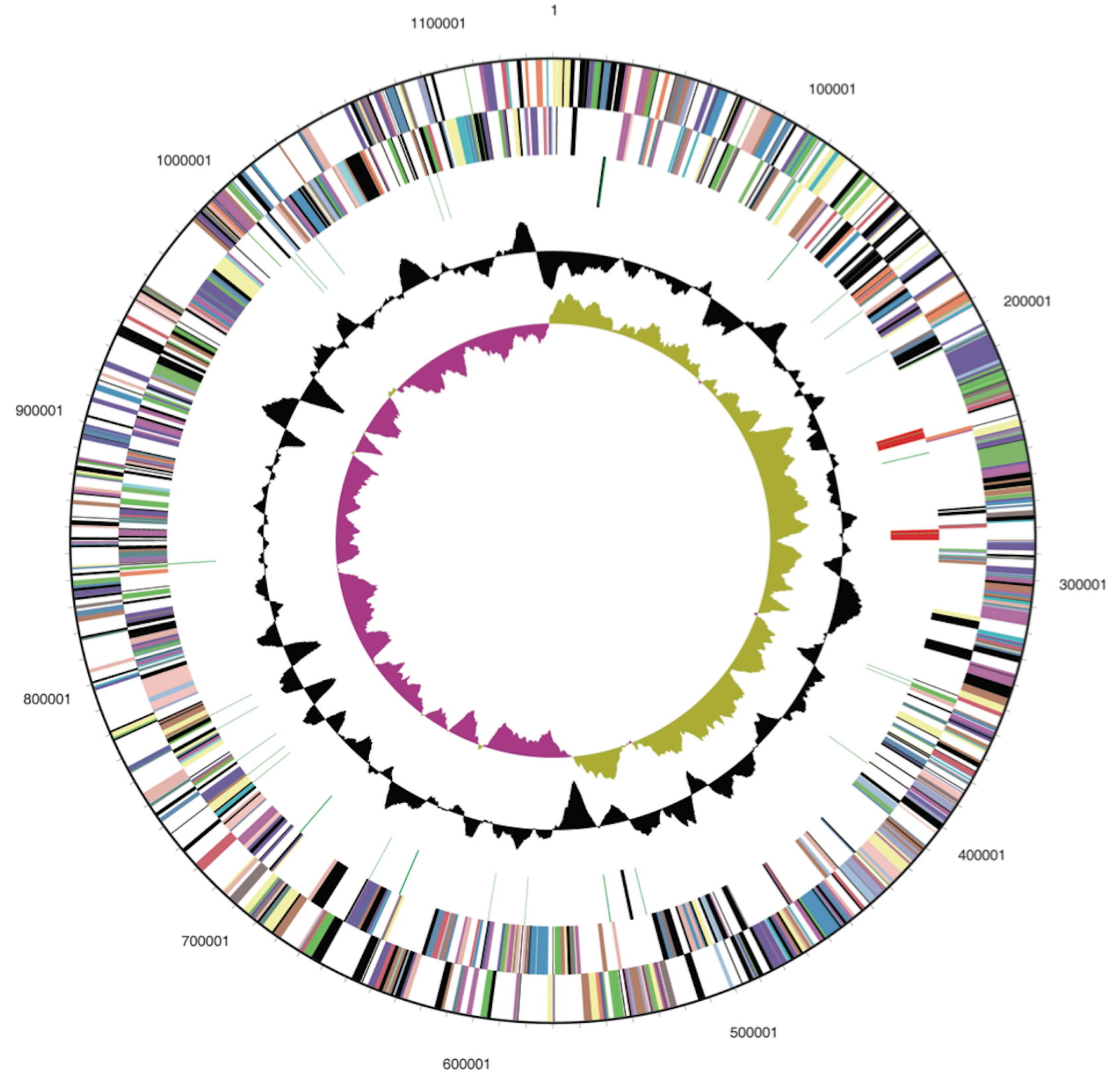

Figure 2. Graphical circular map of the T. pallidum strain DAL-1 genome. From the outside to the center: Genes on forward strand (color by COG categories), Genes on reverse strand (color by COG categories), RNA genes (tRNAs green, rRNAs red, other RNAs black), GC content, GC skew. The map was generated with help of DOE Joint Genome Institute [41]. 
Table 4. Number of genes associated with general COG functional categories

\begin{tabular}{crrl}
\hline Code & Value & \%age & Description \\
\hline J & 117 & 14.30 & Translation, ribosomal structure and biogenesis \\
K & 31 & 3.79 & Transcription \\
L & 59 & 7.21 & Replication, recombination and repair \\
D & 16 & 1.96 & Cell cycle control, cell division, chromosome partitioning \\
V & 7 & 0.86 & Defense mechanisms \\
T & 38 & 4.64 & Signal transduction mechanisms \\
M & 67 & 8.19 & Cell wall/membrane biogenesis \\
N & 50 & 6.11 & Cell motility \\
U & 36 & 4.40 & Intracellular trafficking and secretion \\
O & 47 & 5.75 & Posttranslational modification, protein turnover, chaperones \\
C & 40 & 4.89 & Energy production and conversion \\
G & 44 & 5.38 & Carbohydrate transport and metabolism \\
E & 26 & 3.18 & Amino acid transport and metabolism \\
F & 23 & 2.81 & Nucleotide transport and metabolism \\
H & 23 & 2.81 & Coenzyme transport and metabolism \\
I & 20 & 2.44 & Lipid transport and metabolism \\
P & 26 & 3.18 & Inorganic ion transport and metabolism \\
Q & 3 & 0.37 & Secondary metabolites biosynthesis, transport and catabolism \\
R & 83 & 10.15 & General function prediction only \\
S & 62 & 7.58 & Function unknown \\
- & 366 & - & Not in COGs \\
\hline
\end{tabular}

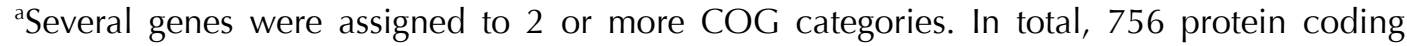
genes were 818-times assigned to COGs.

\section{Acknowledgements}

The authors thank Dr. David Cox for providing the DAL1 strain and Dr. Nikos C. Kyrpides (DOE Joint Genome Institute) for COG calculations. This work was supported by grants from the U.S. Public Health Service to

\section{References}

1. Fraser CM, Norris SJ, Weinstock CM, White O, Sutton GG, Dodson R, Gwinn M, Hickey EK, Clayton R, Ketchum KA, et al. Complete genome sequence of Treponema pallidum, the syphilis spirochete. Science 1998; 281:375-388. PubMed http://dx.doi.org/10.1126/science.281.5375.375

2. Matějková $P$, Strouhal $M$, Šmajs D, Norris $S J$, Palzkill T, Petrosino JF, Sodergren E, Norton JE, Singh J, Richmond TA, et al. Complete genome sequence of Treponema pallidum ssp pallidum
G.M.W. (R01 DE12488 and R01 DE13759), and by the grants of the Grant Agency of the Czech Republic (310/07/0321), and the Ministry of Education of the Czech Republic (VZ MSM0021622415) to D.S.

strain SS14 determined with oligonucleotide arrays. BMC Microbiol 2008; 8:76. PubMed http://dx.doi.org/10.1186/1471-2180-8-76

3. Giacani L, Jeffrey BM, Molini BJ, Le HT, Lukehart SA, Centurion-Lara A, Rockey DD. Complete genome sequence and annotation of the Treponema pallidum subsp. pallidum Chicago strain. J Bacteriol 2010; 192:2645-2646. PubMed http://dx.doi.org/10.1128//B.00159-10 
4. Čejková D, Zobaníková M, Chen L, Pospíšilová P, Strouhal M, Qin X, Mikalová L, Norris SJ, Muzny DM, Gibbs RA, et al. Whole Genome Sequences of Three Treponema pallidum ssp. pertenue Strains: Yaws and Syphilis Treponemes Differ in Less than $0.2 \%$ of the Genome Sequence. PLoS Negl Trop Dis 2012; 6:e1471. PubMed http://dx.doi.org/10.1371/journal.pntd.0001471

5. Šmajs D, Zobaníková $M$, Strouhal M, Čejková D, Dugan-Rocha S, Pospíšilová P, Norris SJ, Albert T, Qin X, Hallsworth-Pepin K, et al. Complete genome sequence of Treponema paraluiscuniculi, strain Cuniculi A: The loss of infectivity to humans is associated with genome decay. PLoS ONE 2011; 6:e20415. PubMed http://dx.doi.org/10.1371/journal.pone.0020415

6. Šmajs D, Norris SJ, Weinstock GM. Genetic diversity in Treponema pallidum: Implications for pathogenesis, evolution and molecular diagnostics of syphilis and yaws. Infect Genet Evol 2012; 12:191-202. PubMed http://dx.doi.org/10.1016/j.meegid.2011.12.001

7. Wendel GD, Sanchez PJ, Peters MT, Harstad TW, Potter LL, Norgard MV. Identification of Treponema pallidum in amniotic fluid and fetal blood from pregnancies complicated by congenital syphilis. Obstet Gynecol 1991; 78:890-895. PubMed

8. Schaudin FR, Hoffmann E. Vorläufiger Bericht über das Vorkommen von Spirochäten in syphilitischen Krandkheitprodukten und bei Papillomen. Arb K Gesund 1905; 22:527-534.

9. Miao RM, Fieldsteel AH. Genetic relationship between Treponema pallidum and Treponema pertenue, two noncultivable human pathogens. I Bacteriol 1980; 141:427-429. PubMed

10. Castellani A. Further observations on parangi (Yaws). BMJ 1905; 2:1330-1331. PubMed http://dx.doi.org/10.1136/bmj.2.2342.1330-a

11. Field D, Garrity G, Gray T, Morrison N, Selengut J, Sterk P, Tatusova T, Thomson N, Allen MJ, Angiuoli SV, et al. The minimum information about a genome sequence (MIGS) specification. Nat Biotechnol 2008; 26:541-547. PubMed http://dx.doi.org/10.1038/nbt1360

12. Woese CR, Kandler O, Wheelis ML. Towards a Natural System of Organisms: Proposal for the Domains Archaea, Bacteria, and Eucarya. Proc Natl Acad Sci USA 1990; 87:4576-4579. PubMed http://dx.doi.org/10.1073/pnas.87.12.4576

13. Garrity GM, Holt JG. The Road Map to the Manual. In: Garrity GM, Boone DR, Castenholz RW (eds), Bergey's Manual of Systematic Bacteriology, Second Edition, Volume 1, Springer, New York, 2001, p. 119-169.

14. Ludwig W, Euzeby J, Whitman WG. Draft taxonomic outline of the Bacteroidetes, Planctomycetes, Chlamydiae, Spirochaetes, Fibrobacteres, Fusobacteria, Acidobacteria, Verrucomicrobia, Dictyoglomi, and Gemmatimonadetes. http://www.bergeys.org/outlines/Bergeys_Vol_4_ Outline.pdf. Taxonomic Outline 2008.

15. Judicial Commission of the International Committee on Systematics of Prokaryotes. The nomenclatural types of the orders Acholeplasmatales, Halanaerobiales, Halobacteriales, Methanobacteriales, Methanococcales, Methanomicrobiales, Planctomycetales, Prochlorales, Sulfolobales, Thermococcales, Thermoproteales and Verrucomicrobiales are the genera Acholeplasma, Halanaerobium, Halobacterium, Methanobacterium, Methanococcus, Methanomicrobium, Planctomyces, Prochloron, Sulfolobus, Thermococcus, Thermoproteus and Verrucomicrobium, respectively. Opinion 79. Int I Syst Evol Microbiol 2005; 55:517-518. PubMed http://dx.doi.org/10.1099/ijs.0.63548-0

16. Buchanan RE. Studies in the Nomenclature and Classification of the Bacteria: II. The Primary Subdivisions of the Schizomycetes. J Bacteriol 1917; 2:155-164. PubMed

17. Skerman VBD, McGowan V, Sneath PHA. Approved Lists of Bacterial Names. Int J Syst Bacteriol 1980; 30:225-420. http://dx.doi.org/10.1099/00207713-30-1-225

18. Swellengrebel NH. Sur la cytologie comparée des spirochètes et des spirilles. Ann Inst Pasteur (Paris) 1907; 21:562-586.

19. Schaudinn F. Zur Kenntnis der Spirochaete pallida. Dtsch Med Wochenschr 1905; 31:1728. http://dx.doi.org/10.1055/s-0029-1188418

20. Smibert RM. Genus III. Treponema Schaudinn 1905, 1728. In: Buchanan RE, Gibbons NE (eds), Bergey's Manual of Determinative Bacteriology, Eighth Edition, The Williams and Wilkins Co., Baltimore, 1974, p. 175-184.

21. Fieldsteel AH, Cox DL, Moeckli RA. Further studies on replication of virulent Treponema pallidum in tissue cultures of SFLEP cells. Infect Immun 1982; 35:449-455. PubMed 
22. Baseman JB, Nichols JC, Hayes NS. Virulent Treponema pallidum - aerobe or anaerobe. Infect Immun 1976; 13:704-711. PubMed

23. Nichols JC, Baseman JB. Carbon sources utilized by virulent Treponema pallidum. Infect Immun 1975; 12:1044-1050. PubMed

24. Schiller NL, Cox CD. Catabolism of glucose and fatty acids by virulent Treponema pallidum. Infect Immun 1977; 16:60-68. PubMed

25. Turner TB, Hollander DH. Biology of the treponematoses based on studies carried out at the International Treponematosis Laboratory Center of the Johns Hopkins University under the auspices of the World Health Organization. Monogr Ser World Health Organ 1957; 35:3-266. PubMed

26. BAuA. Classification of Bacteria and Archaea in risk groups. www.baua.de TRBA 466 p. 349.

27. Ashburner M, Ball CA, Blake JA, Botstein D, Butler H, Cherry JM, Davis AP, Dolinski K, Dwight SS, Eppig JT et al. Gene ontology: tool for the unification of biology. Nat Genet 2000; 25(1):25-29. pmid: 10802651

28. Project RD.

http://rdp.cme.msu.edu/treebuilderpub/treeHelp.js p.

29. Bruno WJ, Socci ND, Halpern AL. Weighted neighbor joining: a likelihood-based approach to distance-based phylogeny reconstruction. $\mathrm{Mol}$ Biol Evol 2000; 17:189-197. PubMed http://dx.doi.org/10.1093/oxfordjournals.molbev.a $\underline{026231}$

30. Som A. Theoretical foundation to estimate the relative efficiencies of the Jukes-Cantor+gamma model and the Jukes-Cantor model in obtaining the correct phylogenetic tree. Gene 2006;

385:103-110. PubMed http://dx.doi.org/10.1016/j.gene.2006.03.027

31. Jepsen OB, Hougen KH, Birch-Andersen A. Electron microscopy of Treponema pallidum Nichols. Acta Pathol Microbiol Scand 1968; 74:241-258. PubMed http://dx.doi.org/10.1111/j.16990463.1968.tb03477.x

32. Fieldsteel $\mathrm{AH}, \mathrm{Cox} \mathrm{DL}$, Moeckli RA. Cultivation of virulent Treponema pallidum in tissue culture. Infect Immun 1981; 32:908-915. PubMed

33. Norris SJ. Invitro cultivation of Treponema pallidum - independent confirmation. Infect Immun 1982; 36:437-439. PubMed
34. Wagner-Jauregg J. Über die Einwirkung der Malaria auf die progressive Paralyse. Psychiatr Neurol Wochenschr 1918; 20:132-134.

35. Norris SJ, Edmondson DG. Invitro culture system to determine MICS and MBSC of antimicrobial agents against Treponema pallidum subsp. pallidum (Nichols strain). AAC 1988; 32:68-74.

36. Stamm LV, Bergen HL. A point mutation associated with bacterial macrolide resistance is present in both 23S rRNA genes of an erythromycin-resistant Treponema pallidum clinical isolate. AAC 2000; 44(3):806-807. pmcid: 89774

37. Matějková P, Flasarová $M$, Zakoucká $H$, Borek $M$, Křemenová S, Arenberger P, Woznicová V, Weinstock GM, Šmajs D. Macrolide treatment failure in a case of secondary syphilis: a novel A2059G mutation in the 23S rRNA gene of Treponema pallidum subsp pallidum. J Med Microbiol 2009; 58:832-836. PubMed http://dx.doi.org/10.1099/jmm.0.007542-0

38. Liolios K, Chen IM, Mavromatis K, Tavernarakis $\mathrm{N}$, Hugenholtz P, Markowitz VM, Kyrpides NC. The Genomes On Line Database (GOLD) in 2009: status of genomic and metagenomic projects and their associated metadata. Nucleic Acids Res 2010; 38(Database issue):D346-D354. PubMed http://dx.doi.org/10.1093/nar/gkp848

39. Baseman JB, Nichols JC, Rumpp JW, Hayes NS. Purification of Treponema pallidum from infected rabbit tissue - resolution into two treponemal populations. Infect Immun 1974; 10:1062-1067. PubMed

40. Zerbino DR, Birney E. Velvet: Algorithms for de novo short read assembly using de Bruijn graphs. Genome Res 2008; 18:821-829. PubMed http://dx.doi.org/10.1101/gr.074492.107

41. DOE Joint Genome Institute. http://img.jgi.doe.gov/

42. Brinkman MB, McGill MA, Pettersson J, Rogers A, Matejkova P, Smajs D, Weinstock GM, Norris SJ, Palzkill T. A novel Treponema pallidum antigen, TP0136, is an outer membrane protein that binds human fibronectin. Infect Immun 2008; 76:18481857. PubMed http://dx.doi.org/10.1128/IAl.01424-07

43. LaFond RE, Centurion-Lara A, Godornes C, Van Voorhis WC, Lukehart SA. TprK sequence diversity accumulates during infection of rabbits with Treponema pallidum subsp. pallidum Nichols strain. Infect Immun 2006; 74:1896-1906. PubMed http://dx.doi.org/10.1128/IAI.74.3.1896$\underline{1906.2006}$ 
Zobanikova et al.

44. Centurion-Lara A, Godornes C, Castro C, Van Voorhis WC, Lukehart SA. The tprK gene is heterogeneous among Treponema pallidum strains and has multiple alleles. Infect Immun 2000; 68:824831. PubMed

http://dx.doi.org/10.1128/IAl.68.2.824-831.2000

45. Centurion-Lara A, Sun ES, Barrett LK, Castro C, Lukehart SA, Van Voorhis WC. Multiple alleles of Treponema pallidum repeat gene $\mathrm{D}$ in Treponema pallidum isolates. I Bacteriol 2000; 182:2332-

2335. PubMed http://dx.doi.org/10.1128//B.182.8.23322335.2000

46. LaFond RE, Centurion-Lara A, Godornes C, Rompalo AM, Van Voorhis WC, Lukehart SA. Sequence diversity of Treponema pallidum subsp. pallidum tprK in human syphilis lesions and rabbit-propagated isolates. I Bacteriol 2003;

185:6262-6268. PubMed http://dx.doi.org/10.1128//B.185.21.6262$\underline{6268.2003}$
47. Leader BT, Hevner K, Molini BJ, Barrett LK, Van Voorhis WC, Lukehart SA. Antibody responses elicited against the Treponema pallidum repeat proteins differ during infection with different isolates of Treponema pallidum subsp. pallidum. Infect Immun 2003; 71:6054-6057. PubMed http://dx.doi.org/10.1128/IAl.71.10.6054$\underline{6057.2003}$

48. Palmer $\mathrm{GH}$, Bankhead T, Lukehart SA. 'Nothing is permanent but change' - antigenic variation in persistent bacterial pathogens. Cell Microbiol 2009; 11:1697-1705. PubMed http://dx.doi.org/10.1111/j.14625822.2009.01366.x

49. Giacani L, Molini B, Godornes C, Barrett L, Van Voorhis W, Centurion-Lara A, Lukehart SA. Quantitative analysis of tpr gene expression in Treponema pallidum isolates: Differences among isolates and correlation with T-cell responsiveness in experimental syphilis. Infect Immun 2007;

75:104-112. PubMed http://dx.doi.org/10.1128/IAI.01124-06 